\title{
Resúmenes Tesis: Especialización en Administración en Salud con Orientación en Auditoría Bioquímica Integral
}

\section{Evaluación y comparación de los costos extra/intramuros para Herpes Virus por diagnóstico molecular y sus implicancias en el Hospital de Niños de Santa Fe "Dr. Orlando Alassia"}

Mg. Mariana Castañeira

marcastaneira03@hotmail.com

Director: CPN Héctor Deponti

Co-Director: Dra. Mónica Sosa

Lugar de realización: Laboratorio de Biología Molecular. Hospital de Niños "Dr. Orlando Alassia

Fecha de la defensa: 18/03/2015

Introducción: La encefalitis por Virus Herpes Simple (VHS) es una afección grave del sistema nervioso central más frecuente en niños. El diagnóstico es en Líquido cefalorraquídeo (LCR) y la PCR (Reacción de polimerasa en cadena) es el método diagnóstico de elección. Sin tratamiento la mortalidad es del $70 \%$. La supervivencia aumenta si se medica con Aciclovir dentro de los primeros días ante la sospecha de meningoencefalitis herpética. El diagnóstico, medicación e internación tiene costos especiales para los servicios públicos.

Objetivo general: Analizar la conveniencia de implementar una herramienta de diagnóstico según se realice extra/ intramuros en el Hospital de Niños "Dr. Orlando Alassia" de Santa Fe

Objetivos específicos: 1) Caracterizar y determinar los costos del procedimiento diagnóstico según se realice extra/intra- muros. 2) Evaluar el impacto que produce la realización en el hospital de esta técnica en cuanto a costos y tiempo de resolución diagnóstico e internación. 3) Proponer un modelo para seleccionar y realizar nuevas determinaciones moleculares.

Metodología: Se realizó un estudio observacional, descriptivo y transversal. La Unidad de análisis, la determinación "PCR anidada para VHS" en muestras de LCR en mujeres y varones, entre 0 a 14 años (110 en el año 2011 y 188 en el 2012). Se analizaron los costos de estructura o fijos en función del espacio, personal (destinado a la realización de 4 determinaciones, afectación al HSV 25\%), recursos necesarios, estructura y los costos variables ligados directamente a la cantidad de determinaciones producidas (insumos y recursos consumibles). Se utilizó una amortización lineal del equipamiento (igual en todos los años) según su vida útil.

Con el fin de calcular los costos extra/ intramuros y diarios por paciente en internación se realizaron entrevistas semiestructuradas a médicos, prestador privado y personal de administración.

Resultados: En las tablas se muestra la información de los cálculos realizados 
Tabla 1. Costos fijos afectables para la prueba realizada intramuros

\begin{tabular}{l|r|r}
\hline Concepto & $\mathrm{n}=110$ & $\mathrm{n}=188$ \\
\hline Total determinaciones & & \\
$\begin{array}{l}\text { Bioquímico(sueldo+leyessoc+sac+vac) } \\
\text { Afectación a la práctica 25\% }\end{array}$ & $\$ 21.062,50$ & $\$ 25.125,00$ \\
$\begin{array}{l}\text { Personal de limpieza (sueldo+leyes soc+sac+vac) } \\
\text { 1h semanal labor Afectación a la práctica 25\% }\end{array}$ & $\$ 21,75$ & $\$ 468,75$ \\
\hline Equipamiento & $\$ 702,25$ & $\$ 702,25$ \\
\hline Amortización equipo año Afectación a la práctica 25\% & $\$ 201,70$ & $\$ 139,87$ \\
Costo fijo unitario & $\$ 22.186,50$ & $\$ 26.296,00$ \\
\hline
\end{tabular}

Tabla 2. Costos variables para realizar prueba intramuros

\begin{tabular}{l|r|r}
\hline Concepto & \multicolumn{1}{c}{2011} & \multicolumn{1}{c}{2012} \\
\hline Costos variables unitarios & $\$ 45,68$ & $\$ 45,40$ \\
Total costos variables & $\$ 5024,80$ & $\$ 8535,20$ \\
\hline
\end{tabular}

Tabla 3. Costos por derivación

\begin{tabular}{l|r|r}
\hline \multicolumn{2}{c}{2011} & \multicolumn{2}{c}{2012} \\
\hline Arancel $x$ determinación en prestador privado & $\$ 300,00$ & $\$ 400,00$ \\
\hline Flete traslado muestras & $\$ 30,00$ & $\$ 30,00$ \\
\hline Costo unitario total $x$ derivación & $\$ 330,00$ & $\$ 430,00$ \\
\hline
\end{tabular}

El costo unitario para realizar la determinación intramuros fue de \$247,38 (2011) y de $\$ 185,27$ (2012) y el costo total de $\$$ $27.211,30$ en 2011 y $\$ 34.831,20$ en 2012. El costo total por tercerizar hubiera sido de \$36.300,00 en 2011 y \$ 80.840,00 en 2012 (Tabla 3). Comparando los costos intra/ extramuros existe un ahorro por realización de la determinación intramuros de $\$$ $9.088,70$ en 2011 y de $\$ 46.008,80$ en 2012.

El costo por día de internación según el "módulo día terapia intermedia" del nomenclador para hospitales de gestión descentralizados es $\$ 450$ por pacientes. El costo de aciclovir preventivo es de $\$ 140$ promedio por día.
Conclusión: Se produjo un ahorro estimado al realizar la PCR anidada para HSV en el hospital en la suma de \$13.110,00 en el año 2011 (\$119 por determinación) y en el año 2012 de \$50.741,00 (\$269 por determinación). Además se estimó un ahorro por día de internación de \$49.500,00 (2011) y $84.600,00$ (2012). Por Aciclovir preventivo evitable \$15.400,00 (2011) y \$26.320,00 (2012). Se produjo una reducción total anual estimada de $\$ 72.782,90$ (2011) y de $\$ 155.649,00$ (2012). Este trabajo demuestra simplemente que se ha escogido el mejor camino debido a que el costo final para el Hospital se ve sensiblemente reducido, al realizar la determinación en el laboratorio local, sin necesidad de tercerizar. Ade- 
más existe una reducción en el tiempo de entrega de resultado y un impacto en la calidad de atención de los pacientes. Certificar y caracterizar los costos del diagnóstico molecular con sus implicancias en un efector público sirve como modelo para seleccionar nuevas determinaciones y obtener una visión integral en post de la mejora continua de la calidad.

\section{Summary}

Evaluation and comparison of extra/intramural costs for Herpes Virus through molecular diagnosis and its implications on the Children's Hospital in Santa Fe "Dr. Orlando Alassia".

Introduction: Health services quality is linked to careful planning of the infrastructure and economic resources. Encephalitis due to Herpes Simplex Virus (HSV) is a serious condition, predominantly in children. Early diagnosis and treatment decreases mortality, neurological sequels and prolonged hospitalization. PCR (Polymerase Chain Reaction) is the selected method for diagnosis. The chosen technique is Nested PCR. The treatment entails the use of Acyclovir.
Objectives: To calculate and contrast diagnosis procedure costs depending on whether it is done in an extra/intramural way. To evaluate the impact of carrying this technique out in the hospital as regards reduced hospitalization and early treatment.

Methodology: In order to calculate costs we took the registries into account (2011 and 2012): consumables, equipment, human resource (salary and social burden) and invoicing.

Results: The estimated savings as a result of nested PCR for HSV reached the sum of $\$ 13.110$ (2011) and \$ 50.741 (2012). As well as fewer hospitalization $\$ 49.500$ (2011) and 84.600 (2012). Through annual preventative Acyclovir \$15.400 (2011) and $\$ 26.320$ (2012). The estimated annual total reduction was \$72.782,90 (2011) and \$ 155.649,00 (2012).

Conclusions: This piece of work simply proves that the best path has been chosen as the final cost for the Hospital gets significantly reduced by achieving intramural determination. Certification and characterization of the costs of a public effector serves as a model to select new determinations and obtain an integrated vision in the pursuit of constant quality improvement.

\section{Implantación de un Sistema de Costos de Calidad como herramienta de control y mejora del Sistema de Gestión de Calidad de un Laboratorio de Análisis Clínicos}

\author{
María lleana Panozzo \\ mpanozzo28@gmail.com \\ Director / Co-Director: Dra. María Silvia \\ Cámara
}

Lugar de realización: San Cristóbal, Provincia de Santa Fe. Facultad de Bioquímica y Ciencias Biológicas. Universidad Nacional del Litoral.

Fecha de la defensa: 18 de Marzo de 2015 


\section{Resumen}

En toda empresa de servicios la implementación de un Sistema de Gestión de Calidad (SGC) genera costos que sumados a los costos de producción deben ser determinados y medidos.

El reto de las empresas en el mundo de hoy significa establecer estrategias con un enfoque de integralidad encaminadas a alcanzar el máximo beneficio con el menor costo posible.

El presente TFI se desarrolló con el objetivo de diseñar e implementar una metodología para integrar al SGC existente en un laboratorio de análisis clínicos un Sistema de Gestión de Costos de Calidad (SGCC) basado en el enfoque por procesos.

Con la aplicación de la metodología se determinaron los cálculos de los costos de calidad, detallándose las etapas, fases y pasos que servirán como herramienta para introducir cambios importantes tanto en los patrones de comportamiento de los costos relacionados con el servicio, así como su medición y control que posibilite la mejora continua.

Los resultados mostraron que:

Los costos fijos del laboratorio representan el $73 \%$ de los costos totales.

Los costos fijos de mayor incidencia son los de sueldos de los empleados y leyes sociales, los de remuneración profesional y AFIP.

Los costos variables representan el $19 \%$ de los costos totales.

Los costos variables de mayor incidencia son los reactivos y la derivación de prácticas de alta complejidad.

Los costos proporcionales representan el $8 \%$ de los costos totales.
El costo proporcional de mayor incidencia es la retención de la Asociación de Bioquímicos.

El Punto de Equilibrio se encuentra en la coordenada de volumen de 7.547 ingresos / 32.201 prestaciones; \$ 966.055 (CT). Esto significa que son necesarios 7.547 ingresos o 32.201 prestaciones por año para lograr el equilibrio.

Los costos de calidad representan el $7 \%$ de los costos totales y los de producción el $93 \%$.

Dentro de los costos de calidad, los costos de prevención representan un $69 \%$, en tanto los de evaluación un $21 \%$ y los de fallo un $10 \%$

Debido a la permanente devaluación de nuestro sistema monetario, expresar los gastos en UB permite la actualización de los valores que se generan en la producción del laboratorio, ya que la UB se actualiza semestralmente.

El cálculo de costos del laboratorio utilizando un SGCC como soporte, es una herramienta de gestión de gran utilidad para analizar la situación económica financiera de un laboratorio que por ser una empresa con una producción muy heterogénea, el cálculo de los costos de una manera normalizada es importante. Los costos de calidad como instrumentos administrativos de decisión son de gran utilidad para la dirección a fin de cuantificar monetariamente y jerarquizar los costos a la hora de la toma de decisiones trascendentes como invertir, modernizarse, reestructurarse, etc.

El TFI tiene valor metodológico porque se puede adaptar a las características particulares de cada laboratorio pudiendo ser implementado en todo tipo de empresa de análisis clínicos, quedando demostrada la factibilidad práctica y económica de la investigación. 


\section{Summary}

Implementation of a quality system of costs as tool of control and improvement of the quality management system of a clinical analysis laboratory

Across enterprise services implementation of a quality management system (QMS) generates costs which added to production costs must be determined and measured.

The challenge for companies in today's world means to establish strategies with a focus on integration aimed at achieving the maximum benefit with the lowest possible cost.

Present TFI was developed with the objective of designing and implementing a methodology to integrate the QMS in a laboratory of clinical analysis a management system of cost of quality (SGCC) based approach by processes.

With the application of the methodology were determined estimates of the costs of quality, detailing the stages, phases and steps that will serve as a tool to introduce important changes both in the patterns of behaviour of the costs associated with the service, as well as measurement and control enabling continuous improvement.

The calculation of costs of the laboratory using a SGCC as support, is a useful management tool to analyze the economic financial situation of a laboratory that for being a company with a very heterogeneous production, the calculation of costs in a standardized manner is important. Quality as administrative instruments of decision costs of useful for guidance in order to quantify monetarily and rank the costs at the time of decision-making transcendent as investing, modernise, restructure, etc.

TFI has methodological value, because it can adapt to the particular characteristics of each laboratory and applied in every undertaking of clinical analyses demonstrating the economic viability and research practice. 